\title{
Perbedaan Kadar Zinc Rambut dan Asupan Makan pada Balita Stunting dan Non-Stunting di Puskesmas Wilangan Kabupaten Nganjuk
}

\section{Difference of Hair's Zinc Level and Food Intake in Stunted and Non-Stunted Children at Wilangan Health Center, Nganjuk}

\author{
Ririn Kristiani*1, Luki Mundiastuti $^{2}$, Trias Mahmudiono ${ }^{3}$
}

\begin{abstract}
ABSTRAK
Latar Belakang: Permasalahan gizi kronis yang terjadi di dunia dan Indonesia salah satunya adalah stunting. Kurangnya asupan zat gizi merupakan salah satu penyebab langsung terjadinya stunting. Defisiensi zinc dapat menyebabkan kegagalan pertumbuhan, penurunan nafsu makan dan kegagalan perkembangan motorik. Kadar zinc rambut lebih tepat untuk menggambarkan status zinc pada masa lampau dan pelaksanaan yang lebih mudah, penanganan lebih sederhana dan konsentrasinya lebih peka.

Tujuan: Menganalisis perbedaan kadar zinc rambut dan asupan makan (energi, protein, zinc dan zat besi) pada balita stunting dan non-stunting di Puskesmas Wilangan.

Metode: Rancangan yang digunakan yaitu observasional analitik dengan case control design. Jumlah sampel 23 balita stunting dan 23 balita non-stunting. Pengambilan sampel dilakukan secara acak. Data tinggi badan menggunakan mikrotoice, kadar zinc rambut dengan metode Spektrofotometri Serapan Atom, asupan makan dengan food recall 3×24 jam dan wawancara kuesioner. Data dianalisis dengan uji chi-square (kadar zinc rambut), dan t-test dependen (asupan makan). Hasil: Terdapat perbedaan kadar zinc rambut $(p=0,039)$, asupan energi $(p=<0,001)$, asupan protein $(p=<0,001)$, asupan zinc $(p=<0,001)$ dan asupan zat besi $(p=0,003)$ pada balita stunting dan non-stunting.

Kesimpulan: Terdapat perbedaan kadar zinc rambut, asupan energi, protein, zinc dan zat besi balita stunting dan nonstunting. Kadar zinc rambut, asupan energi, protein, zinc dan zat besi pada balita stunting lebih rendah dibandingkan balita non-stunting di wilayah Puskesmas Wilangan.
\end{abstract}

Kata kunci: kadar zinc rambut, stunting, balita

\section{ABSTRACT}

Background: Chronic nutritional problems that occur in the world and Indonesia is stunted. Deficiency of nutrient intake is one of the direct causes of stunted. Zinc deficiency can cause growth failure, decreased appetite and failure of motor development. Zinc hair concentration is more appropriate to describe zinc status in the past and easier implementation, the handling is simpler and concentration is more sensitive.

Objectives: Analyzing differences of zinc hair concentration and food intake (energy, protein, zinc and iron) on stunted and non-stunted under five years old children at the working area of Wilangan Health Center.

Methods: This was analytic observational with cross sectional study. Total of samples was 23 stunted toddlers and 23 nonstunted toddlers. Samples were taken randomly. Body height data using mikrotoice, zinc hair concentration with Atomic Absorption Spectrophotometry, food intake with $3 \times 24$ hours food recall and questionnaire interviews. Data were analyzed by chi-square, independent $t$-test and logistic regression.

Results: There was differences in hair zinc levels $(p=0.039)$, energy intake $(p=<0.001)$, protein intake $(p=<0.001)$, zinc intake $(p=<0.001)$ and iron intake ( $p=0.003)$.

Conclusions: There was difference betwen low zinc hair levels, energy, protein, zinc and iron intake in toodlers stunted and non-stunted. Hair zinc levels, energy, protein, zinc and iron intake in toodlers stunted was lower than non-stunted at Wilangan Health Health Center.

Keywords: hair zinc levels, stunted, toodler 


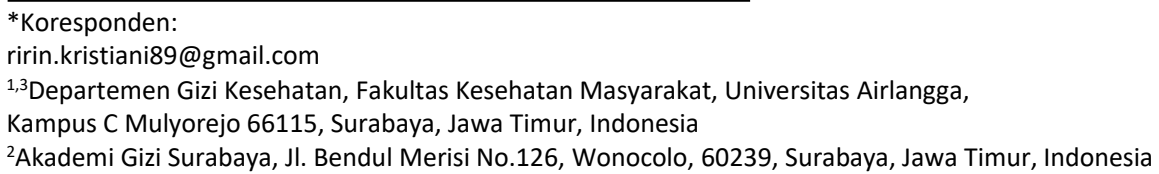

\section{PENDAHULUAN}

Prevalensi stunting di dunia pada tahun 2016 pada balita yaitu 154,8 juta (22,9\%), terbesar di benua Asia (56\%) dan Afrika $(38 \%)^{1}$. Masalah stunting di Indonesia masih belum terselesaikan. Berdasarkan hasil RISKESDAS, terjadi angka kejadian stunting meningkat dari $35,6 \%$ (tahun 2010) menjadi 37,2\% (tahun 2013) artinya 1 dari 3 anak Indonesia mengalami stunting ${ }^{2}$. Perkembangan dan pertumbuhan balita stunting dapat terhambat sehingga secara tidak langsung dapat menyebabkan balita dengan stunting pada saat dewasa berpotensi untuk memiliki pendidikan yang lebih rendah, berpendapatan rendah dan berisiko lebih tinggi untuk terkena penyakit tidak menular ${ }^{3}$. Situasi ini apabila tidak diatasi dapat mempengaruhi kinerja, pertumbuhan ekonomi dan kemiskinan di Indonesia ${ }^{4}$. Stunting merupakan salah satu prioritas dalam Rencana Pembangunan Jangka Menengan (RPJM) tahun 20152019 yaitu sebagai upaya dalam peningkatan status gizi masyarakat ${ }^{5}$.

Konsumsi makanan yang mengandung zat gizi seperti energi, protein, zinc dan zat besi serta riwayat penyakit infeksi merupakan faktor yang berhubungan langsung terhadap stunting ${ }^{6}$. Kurangnya asupan gizi akan menyebabkan bertambahnya jumlah growth failuering (gangguan pertumbuhan pada anak) ${ }^{7}$. Energi berperan dalam pemeliharaan tubuh, metabolisme basal, perbaikan sel dan jaringan karena suatu penyakit dan keseluruhan kegiatan lainnya yang dilakukan oleh tubuh untuk pertumbuhan ${ }^{8}$. Rendahnya asupan energi merupakan salah satu faktor penentu terjadinya masalah pertumbuhan ${ }^{9}$. Protein berperan dalam mengatur, membangun dan sumber tenaga yang digunakan seharihari ${ }^{10}$. Zinc merupakan mikronutrien yang paling berpengaruh pada kejadian stunting, karena defisiensi zinc dapat menyebabkan gangguan nafsu makan (anoreksia) sehingga menyebabkan asupan makan menjadi kurang dan berdampak pada terganggunya pertumbuhan balita, dan menurunkan sistem imun sehingga dapat meningkatkan frekuensi sakit ${ }^{11}$. Defisiensi zinc terjadi pada $1 / 3$ populasi dunia dan merupakan komplikasi dari keadaan kurang gizi ${ }^{12}$. Indonesia merupakan salah satu negara yang dinyatakan oleh WHO berisiko kekurangan asupan makan sumber zinc, karena rata-rata orang Indonesia hanya mengkonsumsi setengah dari kecukupan gizi yang dianjurkan ${ }^{13}$. Zat besi berperan dalam mengangkut sari makanan ke seluruh tubuh, sehingga sangat berpengaruh dalam pertumbuhan, produksi energi dan sistem kekebalan tubuh ${ }^{14}$. Defisiensi zat besi pada masa balita dapat menyebabkan terhambatnya pertumbuhan sehingga menyebabkan stunting ${ }^{15}$. Penelitian terdahulu yang sudah dilakukan mengungkapkan beberapa faktor risiko stunting yaitu jenis kelamin, umur balita, ketersediaan makan yang meliputi kuantitas asupan makan, jumlah pendapatan keluarga, status dan jenis pekerjaan orang tua ${ }^{16}$. Hal yang menjadi dasar penyebab kekurangan gizi kronis di masyarakat adalah masalah ekonomi yang rendah ${ }^{17}$.

Kabupaten Nganjuk adalah kabupaten yang termasuk dalam 100 kabupaten atau kota prioritas untuk intervensi stunting, prevalensi balita stunting yaitu sebesar 44,33\%4,18. Berdasarkan studi pendahuluan laporan penimbangan pada bulan Agustus 2017 diketahui Puskesmas Wilangan dengan prevalensi stunting tinggi $(39,5 \%)$. Perlu penanganan serius dalam masalah stunting yang masih tinggi pada balita di wilayah Puskesmas Wilangan, agar dapat meminimalisir peningkatan masalah stunting yang dapat makin meningkat jika tidak medapat perhatian ${ }^{19}$. Kondisi stunting baru nampak setelah usia 2 tahun ${ }^{20}$. Berdasarkan penelitian Ramli, et al (2009) dan Kurniasari, et al (2016) prevalensi stunting lebih tinggi ada anak usia 2 tahun ${ }^{16,21}$. Penelitian ini juga akan mengukur kadar zinc rambut balita karena kadar zinc rambut dapat menggambarkan status zinc masa lampau ${ }^{22}$. Selain itu pemeriksaan dengan unsur rambut balita jika dibandingkan dengan darah dan urin lebih mudah, sederhana, hasilnya lebih peka, serta menghindari risiko infasif yang mungkin terjadi bila dibandingkan dengan pengambilan serum zinc ${ }^{23,24}$. Dalam darah/serum zinc berkaitan dengan albumin, sehingga hal ini dapat mengakibatkan perubahan kadar zinc serum apabila kadar albumin berubah, oleh karena itu pemeriksaan zinc pada serum kurang tepat untuk menggambarkan status zinc tubuh pada masa lampau, zinc serum lebih tepat untuk menggambarkan perubahan status zinc pada suatu penyakit yang terjadi ${ }^{25}$. Oleh karena itu peneliti ingin menganalisis perbedaan kadar zinc rambut dan asupan makan (energi, protein, zinc dan zat besi) yang dilakukan pada kelompok balita stunting dan non-stunting pada uisa 24-59 bulan di wilayah kerja Puskesmas Wilangan.

\section{METODE}

Jenis penelitian observasional analitik dengan rancangan desain case control. Populasi pada penelitian ini adalah semua anak yang ada dan terdaftar serta berdomisili pada wilayah Puskesmas Wilangan Kabupaten Nganjuk, berusia 24-59 bulan. Berdasarkan survey pendahuluan, telah dilakukan screening terhadap jumlah balita usia 24-59 bulan dengan menggunakan laporan penimbangan bulanan (laporan elektronik Pencatatan dan Pelaporan Gizi Berbasis Masyarakat) dengan jumlah 179 orang yang terdiri dari 71 orang dengan status stunting dan 108 orang dengan status non-stunting. Perhitungan banyak sampel yang digunakan yaitu dengan rumus uji hipotesis dua proporsi dengan menurut Lemeshow (1997), sehingga didapatkan besar sampel minimal yaitu sebesar 23 orang pada setiap kelompok ${ }^{26}$. Jumlah sampel pada penelitian ini 23 balita stunting dan 23 balita non-stunting yang 


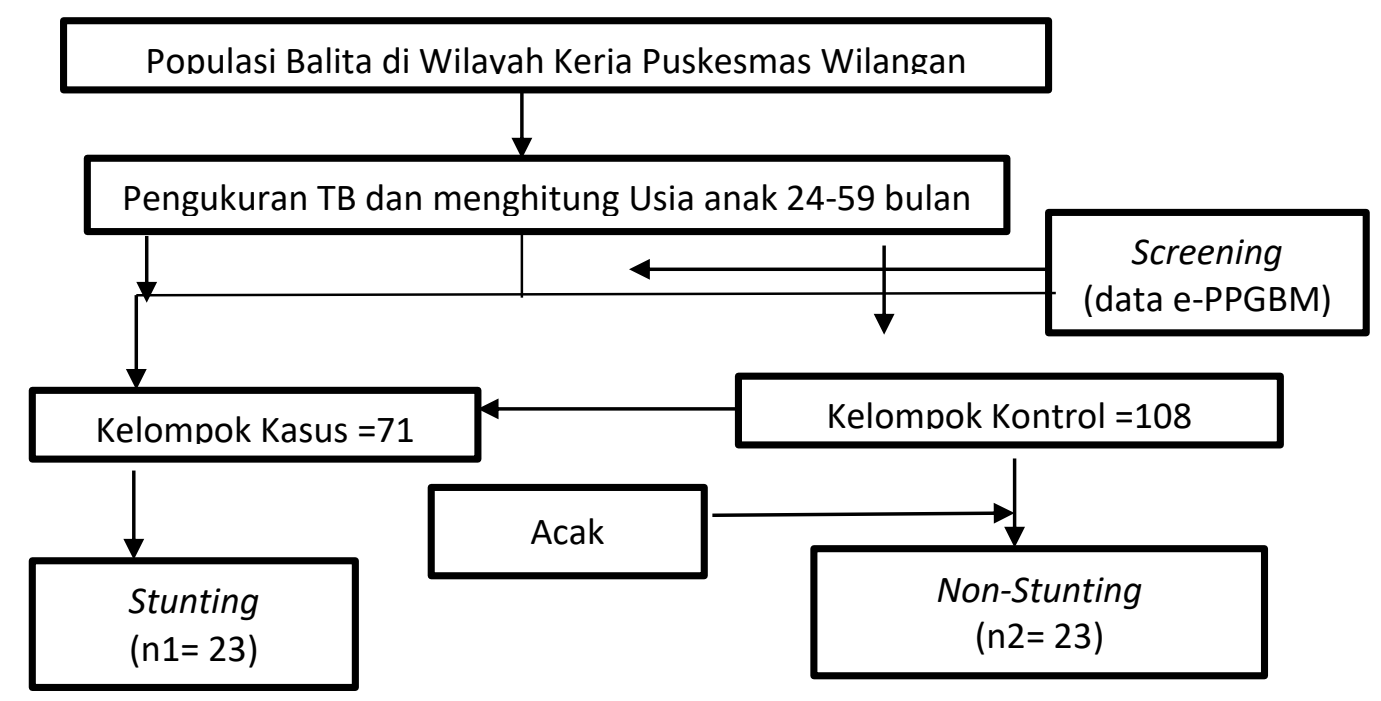

Gambar 1. Kerangka Sampel

diambil secara acak dari total balita stunting dan nonstunting berdasarkan hasil screening (gambar 1).

Kriteria inklusi subyek (balita) dalam penelitian ini yaitu balita dengan usia 24-59 bulan pada saat dilakukan penelitian; tinggal dan menetap di wilayah kerja Puskesmas Wilangan; balita tidak memiliki cacat tubuh; balita memiliki panjang rambut minimal $1,5 \mathrm{~cm}$ dari akar rambut; rambut balita tidak dicat/diwarnai.

Kriteria inklusi responden (ibu balita) yaitu ibu yang memiliki anak usia 24-59 bulan saat penelitian; ibu bersedia menjadi responden serta mengijinkan balitanya diukur kadar zinc rambut dilanjutkan dengan penandatanganan informed consent dan ibu tidak mengalami gangguan pendengaran dan mudah berkomunikasi.

Teknik pengambilan sampel dengan simple random sampling pada kedua kelompok, yaitu stunting dan non-stunting, masing-masing sebanyak 23 balita. Variabel terikat yang dianalisis adalah status stunting, sedangkan variabel bebas yaitu kadar zinc rambut, asupan energi, protein, zinc dan zat besi.

Usia dan jenis kelamin merupakan karakteristik balita yang diteliti. Pendidikan yang telah ditempuh ibu, total pendapatan yang dihasilkan keluarga dalam satu bulan, dan status pekerjaan yang menentukan apakah ibu bekerja atau tidak merupakan karakteristik keluarga yang diteliti. Umur balita digolongkan menjadi dua kategori, yaitu Batita (24-36 bulan) dan pra sekolah (3759 bulan). Data pendidikan ibu balita digolongkan menjadi dua golongan yaitu golongan rendah (<SMA/sederajat) dan tinggi ( $\geq \mathrm{SMA} /$ sederajat). Data pendapatan keluarga digolongkan menjadi dua yaitu berdasarkan peraturan Gubernur Jawa Timur, 2017 Dibawah UMK (< Rp. 1660.044,69) dan diatas UMK ( $\geq$ Rp. $1660.044,69)^{27}$.

Data status pekerjaan oleh ibu dibagi menjadi dua golongan yaitu ibu bekerja dan tidak bekerja (sebagai IRT). Data karakteristik balita dan keluarga diperoleh dengan menggunakan kuesioner. Data tinggi badan dengan menggunakan mikrotoice dengan ketelitian 0,1 cm merk GEA yang dilakukan oleh peneliti. Tinggi badan diukur dengan cara balita berdiri tegak pada lantai yang rata, tidak menggunakan alas kaki, kepala sejajar dengan mata melihat lurus ke depan, kaki rapat menyatu, lutut lurus, tumit, bokong menyentuh dinding yang lurus, tangan di sisi badan, bar pengukur diturunkan hingga menyentuh puncak kepala, dan angka yang paling mendekati denga skala milimeter ${ }^{28}$.

Kemudian dibandingkan dengan standar tinggi badan berdasarkan WHO dengan memperhatikan usia, jenis kelamin, dengan menggunakan software WHO Antro 2005, digolongkan menjadi dua yaitu stunting ( $z$ score $\mathrm{TB} / \mathrm{U}<-2 \mathrm{SD}$ ) dan non-stunting ( $z$-score $\mathrm{TB} / \mathrm{U} \geq-2$ $\mathrm{SD}$ ). Data asupan makan (energi, protein, zinc dan zat besi) menggunakan food recall $3 \times 24$ jam pada waktu yang tidak berurutan, yaitu selama 3 hari tidak berturutturut dengan mempertimbangkan weekdays ( 2 hari) dan weekend (1 hari).

Wawancara recall asupan makan dilakukan oleh peneliti, kemudian dianalisis dengan nutrisurvey dan dirata-ratakan, kemudian dibandingkan dengan standar AKG tahun 2013 dengan dua golongan kategori yaitu asupan kurang $(<77 \%$ AKG) dan asupan cukup $(\geq 77 \%$ $A K G)^{28}$. Data kadar zinc rambut dengan mengambil sampel rambut bagian belakang dengan berat maksimal 0,5 $\mathrm{mg}$ atau 1-3 cm dari akar rambut sebanyak 3-5 helai. Kadar zinc rambut dianalisis dengan metode Spektrofotometer Serapan Atom (SSA) yang dilakukan di Laboratorium Balai Penelitian dan Konsultasi Industri Surabaya.

Kadar zinc rambut dikategorikan menjadi dua kelompok, yaitu kurang $(<150 \mathrm{ppm}$ ) dan normal ( $\geq 150$ $p p m)^{29,30}$. Bentuk penyajian hasil penelitian dengan mengguankan tabel frekuensi dan persentase masingmasing variael pada analisis deskriptif. Uji beda pada variabel yang berskala karegorial yaitu karakteristik balita, karakteristik keluarga, status kadar zinc rambut dan status stunting dengan uji chi-square. Variabel yang berskala data rasio yaitu asupan energi, asupan protein, asupan zinc, asupan zat besi dan $z$-score TB/U dengan $t$ test independen tingkat kemaknaan $p<0,05$ dan interval kepercayaan $95 \%$ pada analisis inferensial.

Penelitian ini sudah memenuhi persyaratan dan ijin persetujuan oleh Komisi Etik Fakultas Kesehatan 
Masyarakat Universitas Airlangga Surabaya, Nomor 374KEPK yang diberikan pada 9 Juli 2018 dan KESBANGPOLLINMAS Daerah Kabupaten Nganjuk dengan Nomor 072/194/411.700/2018 yang diberikan pada 21 Juni 2018.

\section{HASIL DAN PEMBAHASAN}

Analisis perbedaan karakteristik balita, keluarga dan kadar zinc rambut pada balita stunting dan nonstunting dapat dilihat pada tabel 1 . Tidak ada perbedaan usia balita pada kelompok stunting dan non-stunting pada penelitian ini $(p=1,000)$. Tidak ada perbedaan signifikan pada jenis kelamin antara balita stunting dan non-stunting $(p=1,000)$. Usia dan jenis kelamin bukanlah faktor penyebab langsung yang dapat mempengaruhi kejadian stunting, namun masih banyak faktor langsung yang dapat mempengaruhi kejadian stunting seperti asupan makan dan kejadian penyakit infeksi ${ }^{31}$. Tidak ada perbedaan signifikan pada pendidikan ibu antara balita stunting dan non-stunting $(p=0,760)$. Pendapatan keluarga pada balita stunting mayoritas pada kategori dibawah UMK $(57,7 \%)$ sedangkan pada balita non- stunting mayoraitas pada kategori diatas UMK (60\%). Tidak ada perbedaan yang signifikan pada pendapatan keluarga antara balita stunting dan non-stunting $(p=0,234)$. Status pekerjaan ibu pada balita stunting maupun non-stunting mayoritas tidak bekerja yaitu sebesar $78,3 \%$ pada balita stunting dan $73,9 \%$ pada balita non-stunting. Tidak ada perbedaan yang signifikan berdasarkan status pekerjaan pada ibu antara balita yang stunting dan balita yang non-stunting $(p=0,730)$. lbu yang hanya mengurus rumah tangga dan keluarga diharapkan dapat memberikan pola asuh yang baik sehingga dapat memperhatikan pola makan balita sehingga tidak mengalami stunting, namun demikian ibu yang bekerja juga merupakan salah satu alasan menambah pendapatan keluarga agar dapat meningkatkan dalam pemenuhan pangan keluarga, agar ketersediaan jumlah makan keluarga dapat tercukupi dan dapat lebih beragam ${ }^{32}$.

Status kadar zinc rambut pada balita stunting mayoritas dalam kategori kurang yaitu sebesar $65,2 \%$, sedangkan mayoritas pada balita non-stunting dalam kategori normal yaitu sebesar $65,2 \%$.

Tabel 1. Distribusi Karakteristik Balita, Karakteristik Keluarga dan Status Kadar Zinc Rambut pada Balita Stunting dan Non-Stunting Wilayah Kerja Puskesmas Wilangan tahun 2018

\begin{tabular}{|c|c|c|c|c|c|c|}
\hline & \multirow{2}{*}{ Variable } & \multicolumn{2}{|c|}{ Stunting } & \multicolumn{2}{|c|}{ Non stunting } & \multirow[t]{2}{*}{ P-Value } \\
\hline & & $\mathrm{n}$ & $\%$ & $n$ & $\%$ & \\
\hline \multirow{2}{*}{ Usia } & Batita & 7 & 30,4 & 7 & 30,4 & \multirow{2}{*}{1,000} \\
\hline & Pra Sekolah & 16 & 69,6 & 16 & 69,6 & \\
\hline \multirow{2}{*}{ Jenis Kelamin } & Laki-laki & 9 & 39,1 & 9 & 39,1 & \multirow{2}{*}{1,000} \\
\hline & Perempuan & 14 & 60,9 & 14 & 60,9 & \\
\hline \multirow{2}{*}{ Pendidikan Ibu } & Rendah & 14 & 60,9 & 15 & 65,2 & \multirow{2}{*}{0,760} \\
\hline & Tinggi & 9 & 39,1 & 8 & 34,8 & \\
\hline \multirow{2}{*}{$\begin{array}{l}\text { Pendapatan } \\
\text { keluarga }\end{array}$} & Dibawah UMK & 15 & 65,2 & 11 & 47,8 & \multirow{2}{*}{0,234} \\
\hline & Diatas UMK & 8 & 34,8 & 12 & 52,2 & \\
\hline \multirow{2}{*}{ Pekerjaan Ibu } & Bekerja & 5 & 21,7 & 6 & 26,1 & \multirow{2}{*}{0,730} \\
\hline & Tidak Bekerja & 18 & 78,3 & 17 & 73,9 & \\
\hline \multirow{2}{*}{$\begin{array}{l}\text { Status Kadar } \\
\text { Zinc Rambut }\end{array}$} & Kurang (<150 ppm) & 15 & 65,2 & 8 & 34,8 & \multirow{2}{*}{$0,039 *$} \\
\hline & Normal ( $\geq 150$ ppm) & 8 & 34,8 & 15 & 65,2 & \\
\hline
\end{tabular}

*signifikan menggunakan uji chi-square, $\alpha=0,05$

Tabel 2. Analisis Perbedaan Rata-rata Asupan Energi, Protein, Zinc dan Zat besi pada Kelompok Balita Stunting dan NonStunting Wilayah Kerja Puskesms Wilangan Tahun 2018.

\begin{tabular}{|c|c|c|c|}
\hline \multirow{2}{*}{ Variable } & Stunting & Non-Stunting & \multirow{2}{*}{ P-value } \\
\hline & Mean \pm SD & Mean \pm SD & \\
\hline Asupan Energi (kkal) & $768,63 \pm 150,69$ & $1138,44 \pm 252,65$ & $<0,001 *$ \\
\hline Asupan Protein (gr) & $28,13 \pm 6,64$ & $37,24 \pm 7,30$ & $<0,001 *$ \\
\hline Asupan Zinc (mg) & $3,08 \pm 0,79$ & $4,19 \pm 0,71$ & $<0,001 *$ \\
\hline Asupan Zat Besi (mg) & $5,23 \pm 1,87$ & $6,98 \pm 1,88$ & $0,003 *$ \\
\hline
\end{tabular}

*signifikan menggunakan uji independent t-test, $\alpha=0,05$ 
Berdasarkan uji chi-square dengan $\alpha=0,05$ menunjukkan nilai $p=0,039$ yang menyimpulkan bahwa ada perbedaan yang signifikan kadar zinc rambut antara balita stunting dan non-stunting. Penelitian dengan mengukur kadar zinc rambut juga pernah dilakukan di kota Surabaya yang menggambarkan konsentrasi kadar zinc rambut yang kurang $(<150 \mathrm{ppm})$ mayoritas terjadi pada kelompok balita stunting ${ }^{33}$.

Permasalahan kurang gizi kronis pada balita yang merupakan efek dari kurangnya asupan makan termasuk kurangnya makanan sumber zinc dalam jauh sebelum waktu sekarang hal ini dapat di ketahui dengan gambaran pada kadar zinc rambut yang rendah ${ }^{22}$. Kadar zinc rambut yang rendah pada balita stunting pada penelitian ini dapat menjadi indikator rendahnya status zinc dalam tubuh22. Tanda klinis defisiensi zinc pada balita seperti gangguan pertumbuhan juga dapat menyebabkan gangguan nafsu makan (anoreksia) yang dapat berhubungan dengan kadar zinc rambut yang rendah $(<150 \mathrm{ppm})^{28}$.

Anoreksia dapat mengakibatkan penurunan asupan energi sekitar $20 \%$ lebih rendah dari pada keadaan umumnya, hal ini juga berpengaruh pada peningkatan laju sintensis pemecahan protein, menurunkan absrobsi lemak dan protein dari makanan sehingga menyebabkan penurunan absrobsi energi yang berasal dari makanan dibandingkan dengan keadaan normal ${ }^{34}$.

Penelitian serupa mengenai kadar zinc rambut yang dilakukan oleh Rahmawati dan Wirawanni (2012) pada anak usia 6-9 tahun menunjukkan bahwa ada perbedaan kadar zinc rambut yang diukur dengan pembagian tingkatan kejadian stunting serta terdapat hubungan positif antara hasil kadar zinc rambut dengan status gizi (TB/U), hubungan positifnya yaitu meningkatnya kadar zinc rambut bersamaan dengan meningkatnya status gizi $(T B / U)^{22}$. Penelitian yang dilakukan oleh Paschalia (2014) dengan hasil rata-rata kadar zinc rambut pada balita stunting lebih rendah dibandingkan dengan kelompok balita non-stunting ${ }^{35}$. Penelitian dengan sasaran usia 12-24 bulan juga dilakukan di Semarang menunjukkan hasil sebaliknya, yaitu tidak ada hubungan antara kadar zinc rambut dengan status gizi $(\mathrm{PB} / \mathrm{U})^{24}$.

Perbedan asupan makan (energi, protein, zinc dan zat besi) pada balita stunting dan non-stunting dapat dilihat pada tabel 2. Hasil penelitian menunjukan adanya perbedaan bermakna berdasarkan asupan energi kelompok balita stunting dan kelompok non-stunting $(p<0,001)$. Rata-rata asupan energi pada kelompok balita stunting (768,63 $\pm 150,69$ kkal), berada dibawah kecukupan rata-rata energi populasi balita usia 24-59 bulan menurut AKG $(1362,5 \mathrm{kkal})^{36}$. Jika dibandingkan dengan AKG tahun 2013 maka rata-rata konsumsi energi pada balita stunting baru memenuhi $56,29 \%$. Hal ini menunjukkan bahwa rata-rata subjek balita stunting di wilayah kerja Puskesmas Wilangan kurang asupan energi $(<77 \%)$. Kurangnya asupan energi pada balita stunting di Wilayah Kerja Puskesmas Wilangan dapat terjadi karena kurangnya kuantitas asupan makan pada kelompok balita stunting.
Perilaku makan anak yang susah makan, kurang nafsu makan dan ketersediaan makan yang terbatas yang dapat disebabkan kurangnya pendapatan keluarga dapat menjadi faktor penyebab kurangnya asupan energi pada kelompok balita stunting ${ }^{17,37}$. Penelitian ini sejalan dengan penelitian yang dilakukan oleh Hermina dan Prihartini (2010) terhadap data konsumsi yang diperoleh dari hasil RISKESDAS 2010, menunjukkan hasil bahwa balita stunting usia 24-59 bulan lebih banyak mengalami kekurangan asupan energi dibandingkan dengan balita non-stunting ${ }^{9}$. Hal ini menunjukkan rendahnya asupan energi dapat mengakibatkan masalah gizi dan gangguan pertumbuhan. Terhambatnya pertumbuhan tinggi badan balita jika dibandingkan usia merupakan cerminan kurangnya asupan energi yang terjadi terus menerus pada jangka waktu lama ${ }^{38}$. Asupan makanan sumber energi merupakan gambaran dari kecukupan makanan dan mengandung berbagai macam zat gizi sesuai dengan jenis makanan yang dikonsumsi, oleh karena itu kekurangan energi merupakan salah satu faktor resiko utama terjadinya stunting ${ }^{8}$.

Adanya perbedaan yang bermakna berdasarkan asupan protein kelompok balita stunting dan kelompok balita non-stunting $(p<0,001)$ pada penelitian ini. Ratarata asupan protein kelompok balita non-stunting lebih tinggi dari balita stunting $(37,24 \pm 7,30 \mathrm{gr})$. Rata-rata asupan protein pada balita stunting $(28,13 \pm 6,64 \mathrm{gr})$, berada dibawah kecukupan rata-rata protein balita pada kelompok usia 24-59 bulan menurut AKG $(30,5 \mathrm{kkal})^{36}$. Asupan protein pada kelompok balita stunting di wilayah kerja Puskesmas Wilangan lebih rendah dibandingkan non-stunting dapat disebabkan selain karena kurangnya asupan dari segi kuantitas juga dari segi kualitas adalah bahan makanan yang paling sering dikonsumsi adalah dari bahan makanan sumber nabati yaitu kacangkacangan.

Asupan protein balita dianjurkan harus sebagian besar merupakan sumber kualitas tinggi yang lebih banyak mengandung asam amino essensial seperti yang terkandung dalam produk hewani ${ }^{10}$. Penelitian serupa dengan hasil yang sama dilakukan oleh Hermina dan Prihartini (2010) terhadap data konsumsi yang diperoleh dari hasil RISKESDAS 2010, yaitu kelompok balita stunting dengan usia 24-59 bulan lebih banyak mengalami kekurangan asupan protein dibandingkan dengan balita non-stunting ${ }^{9}$. Hal ini menunjukkan rendahnya asupan protein dapat mengakibatkan masalah gizi dan gangguan pertumbuhan.

Penelitian lain yang dilakukan oleh Dewi dan Adhi (2016) pada kelompok usia yang sama bahwa balita yang asupan proteinya kurang akan memiliki risiko lebih tinggi sebesar 10,26 kali menjadi stunting dibandingkan dengan balita yang konsumsi proteinya tercukupi 38 . Penelitian yang dilakuan oleh Stehenson, et al (2010) di Kenya dan Nigeria juga menunjukkan hal serupa pada balita 2-5 tahun bahwa asupan protein yang kurang berhubungan dengan kejadian stunting ${ }^{39}$. Peran protein dalam tubuh balita adalah sebagai zat pembangun dan pengatur, selain itu peran protein yang lain juga dapat menjadi sumber tenaga ${ }^{10}$. 
Protein merupakan asam amino essensial untuk pertumbuhan sel dan fungsi otak serta sebagai perlindungan terhadap infeksi (antibody), mengganti sel tubuh yang rusak, sedangkan asam amino berperan sebagai zat pengantar rangsang saraf (neotransmitter) dan dapat mempengaruhi perilaku seperti kontrol emosi dan kontrol diri ${ }^{40,41}$.

Kekurangan asupan energi dan protein dapat berpengaruh pada penurunan sintensis Liver Insulin Growth Factor (IGF-1) yang berperan terhadap hormon pertumbuhan ${ }^{42}$. Oleh karena itu, asupan protein pada balita harus sebagian besar merupakan sumber protein kualitas tinggi yang lebih banyak mengandung asam amino essensial seperti yang terkandung dalam produk hewani ${ }^{40}$. Salah satu hal yang perlu diperhatikan sebagai faktor untuk menentukan laju pertumbuhan balita asalah dengan asupan protein yang baik (kualitas dan kuantitas).

Hasil penelitian menunjukan adanya perbedaan bermakna berdasarkan asupan makan sumber zinc pada kelompok balita stunting dan kelompok non-stunting $(\mathrm{p}<0,001)$. Rata-rata asupan makanan sumber zinc pada balita stunting $(3,08 \pm 0,79 \mathrm{mg})$, berada dibawah kecukupan rata-rata zinc pada kelompok populasi usia 24-59 bulan yang dibandingkan dengan AKG $(4,5 \mathrm{mg})^{36}$. Jika dibandingkan dengan AKG tahun 2013 maka ratarata konsumsi zinc pada balita stunting baru memenuhi $68,44 \%$.

Hal ini menunjukkan bahwa rata-rata subjek balita di wilayah kerja Puskesmas Wilangan kurang asupan zinc ( $<77 \%)$. Penelitian sebelumnya juga tentang asupan makan sumber zinc dan stunting dilakukan di Kota Denpasar dengan hasil adanya perbedaan signifikan antara asupan makan sumber zinc pada kelompok balita stunting dengan kelompok non-stunting, asupan makan sumber zinc lebih tinggi pada kelompok non-stunting ${ }^{43}$. Pada kelompok balita dalam keluarga dengan pendapatan rendah, dapat mengakibatkan asupan zinc yang kurang karena sebagian besar asupan disumbangkan dari bahan sumber makanan nabati dan lebih sedikit dari sumber hewani, yang dimana bahan makanan nabati tinggi fitat dan bioavailabilitasnya lebih rendah daripada hewani ${ }^{44}$.

Penelitian Dewi dan Adhi (2010) menunjukkan balita yang kurang asupan zinc 11,67 kali lebih tinggi berisiko mengalami stunting ${ }^{38}$. Demikian pula pada penelitian Bening, et al (2017) asupan zinc rendah berisiko 2,67 kali lebih tinggi pada kejadian stunting ${ }^{45}$. Kelompok balita lebih rentan mengalami defisiensi zinc, hal ini dapat disebabkan karena pada masa balita pertumbuhan berlangsung cepat dan penyebab utamanya adalah karena kurangnya asupan zinc dari makanan, penyakit yang menyababkan kehilangan zinc dan faktor fisiologis yang menyebabkan kebutuhan zinc meningkat ${ }^{46}$. Fitat, zat besi, dan kalsium sebagai suplement dapat menghambat penyerapan zinc ${ }^{12}$.

Beberapa penelitian yang telah dilakukan sebelumnya menjelaskan defisiensi zinc dapat menganggu pertumbuhan bayi dan juga balita, nafsu makan pada bayi dan balita juga dapat menurun sehingga perkembangan motorik juga dapat terhambat ${ }^{47}$.
Zinc memiliki peran terhadap growth hormone binding RNA, growth hormone reseptor dan IGF-1. Dalam proses penduplikatan dan pembedaan osteoblast dan kondrosit sintensis dan transkripsi somatomedin, kolagen dan osteoklasin, metabolisme zat gizi makro, hal-hal tersebut juga merupakan peran zinc di dalam tubuh $^{11}$.

Kegagalan untuk mencapai pertumbuhan yang maksimal karena kadar IGF-1 yang berada dalam plasma menurun menyebabkan kadar growth hormone juga mengalami penurunan dah hal ini akan menjadi normal kembali setelah zinc diberikan, selain itu juga menyebabkan anoreksia yang dapat mengakibatkan kurangnya asupan energi dan protein yang diperlukan balita untuk proses pertumbuhan ${ }^{11,47}$.

Zinc juga merupakan pembentuk enzim yaitu enzim carbonic anhydrase yang berperan dalam memberikan rangsang untuk mengecap dan mencium aroma makanan, pada defisiensi zinc maka enzim ini berkurang sehingga menyebabkan sel-sel perasa untuk mengecap dan mencium terganggu ${ }^{13}$. Zinc juga berperan penting dalam sistem kekebalan tubuh yang merupakan mediator potensial pertahanan tubuh terhadap infeksi, hal ini dapat terlihat pada penderita defisiensi zinc sering ditemukan limfoneia, konsentrasi dan fungsi limfosit $T$ dan B menurun, serta menurunnya fungsi leukosit ${ }^{35}$.

Perbedaan bermakna juga ditunjukkan berdasarkan asupan makan sumber zat besi pada kelompok stunting dibandingkan kelompok non-stunting $(p=0,003)$. Rata-rata asupan makan sumber zat besi pada stunting $(5,23 \pm 1,87 \mathrm{mg})$, berada dibawah kecukupan rata-rata zat besi populasi balita usia 24-59 bulan menurut AKG $(8,5 \mathrm{mg}){ }^{36}$. Jika dibandingkan dengan AKG tahun 2013 maka rata-rata konsumsi zat besi pada balita stunting baru memenuhi $61,53 \%$. Hal ini menunjukkan bahwa rata-rata subjek balita di wilayah kerja Puskesmas Wilangan kurang asupan zat besi(<77\%).

Kurangnya asupan zat besi pada balita stunting dapat disebabkan karena kurangnya asupan makan sumber zat besi dan meningkatnya meningkatnya kebutuhan akan zat besi saat masa pertumbuhan pada balita ${ }^{15}$. Asupan makan sumber zat besi yang kurang saat masa balita dapat menjadi penyebab terhambatnya pertumbuhan sehingga apabila kejadian ini selalu berulang-ulang terjadi pada anak dalam waktu yang lama dapat menjadi salah satu penyebab stunting ${ }^{15}$. Penelitian sebelumnya yang telah dilakukan oleh Losong dan Adriani (2017) di Surabaya menunjukkan sebagian besar asupan makan yang berasal dari zat besi pada balita stuntung dalam kategori kurang $(95,2 \%)$ dan pada kelompok balita stunting dan kelompok non stunting asupan zat besinya berbeda signifikan ${ }^{48}$.

Kekurangan zat besi dapat mempengaruhi proses pertumbuhan apabila kekurangan tersebut terjadi pada tingkat yang berat, jadi zat besi dapat menghambat proses pertumbuhan jika dalam keadaan kekurangan karena terganggunya proses terbentukya sel darah merah dan dapat berpengaruh pada zat gizi lainnya yang berperan langsung sehingga akan berpengaruh pula pada pertumbuhan balita ${ }^{42}$. Zat besi berperan dalam mengangkut sari-sari makanan ke seluruh sel tubuh, 
hal ini penting untuk pertumbuhan, sistem kekebalan tubuh dan produksi energi ${ }^{14}$. Kekurangan zat besi lebih banyak ditemukan di negara berkembang, termasuk di Indonesia pada golongan rentan seperti pada anak (1-3 tahun), dan kejadian seperti ini ini dapat dikarenakan kebutuhan akan zat besi yang lebih tinggi pada masamasa pertumbuhan, cadangan zat besi yang berkurang, dan kurangnya asupan makanan sumber zat besi ${ }^{15}$.

Pemberian zinc dan zat besi bila bersama-sama dengan dosis yang sesuai dapat saling membantu dalam proses penyerapannya, namun apabila pemberiannya melebihi dosis maka dapat saling menghambat dalam proses penyerapan, dosis yang dianjurkan yaitu pada zat besi tidak melebihi $25 \mathrm{mg} /$ hari $^{15}$. Sebagian zinc menggunakan alat transport yang sama dengan zat besi yaitu transferin dari usus menuju sirkulasi darah ${ }^{49}$. Apabila perbandingan zat besi dan zinc melebihi 2:1 maka alat angkut yaitu transferin akan menyebabkan penyerapan zinc akan terhambat karena transferin yang digunakan untuk mengangkut zinc berkurang, demikian pula yang terjadi apabila dosis zinc yang diberikan lebih tinggi, maka yang akan terganggu yaitu penyerapan zat besi ${ }^{50}$. Oleh karena itu, perlu pertimbangan dalam hal pemberian suplementasi zinc dan zat besi agar tidak menghambat penyerapan salah satu zat gizi (zinc atau zat besi) ${ }^{15}$.

Penelitian dengan mengukur kadar zinc rambut masih terbatas dan jarang dilakukan. Rambut dipilih sebagai indikator kecukupan zinc karena rambut dapat menyimpan kandungan zinc yang lebih banyak apabila dibandingkan dengan bagian tubuh yang lain seperti pada kulit, pada kuku, pada serum darah, sehingga kadar zinc dapat lebih mudah diketahui24. Penelitian ini memiliki keterbatasan, yaitu tidak memperhitungkan rasio molar fitat sebagai salah satu parameter bioavailabilitas zinc yang dapat menghambat penyerapan zinc dalam tubuh. Molar fitat tidak dapat diperhitungkan karena kerebatasan software yang digunakan untuk menganalisis dan informasi kandungan kuantitas molar fitat pada bahan makanan. Rasio molar fitat terhadap molar zinc dapat menggambarkan rendahnya bioavailabilitas zinc pada balita ${ }^{44}$.

\section{KESIMPULAN}

Terdapat perbedaan signifikan antara kadar zinc rambut, asupan energi, protein, zinc dan zat besi pada kelompok balita stunting dan kelompok non-stunting di wilayah kerja Puskesmas Wilangan Kabupaten Nganjuk. Kadar zinc dan asupan energi, protein, zinc dan zat besi pada balita stunting lebih rendah dibandingkan dengan balita non-stunting. Perlu dilakukan penelitian lebih lanjut dengan memperhitungkan rasio molar fitat.

\section{ACKNOWLEDGEMENT}

Terimakasih penulis ucapkan kepada Puskesmas Wilangan dan seluruh staff serta kader posyandu di wilayah kerja Puskesmas Wilangan yang telah membantu di lapangan sehingga penelitian ini dapat berjalan sesuai dengan waktu dan sasaran. Seluruh dosen dan para staf prodi ilmu Gizi Universitas Airlangga, teristimewa untuk dosen pembimbing atas bantuan, bimbingan, arahan dan waktu yang diberikan kepada penulis, serta teman seperjuangan yang membantu proses penelitian.

\section{Conflict of Interest dan Funding Disclosure}

Penelitian ini didanai oleh Pusat Peningkatan Mutu Sumber Daya Manusia Kesehatan Badan PPSDM Kesehatan Kementerian Kesehatan Republik Indonesia.

\section{REFERENS|}

1. UNICEF, WHO \& World Bank Group. Levels And Trends In Child Malnutrition. (United Nations Children's Fund, the World Health Organization and World Bank Group, 2017).

2. Kemenkes RI. Riset Kesehatan Dasar (RISKESDAS) tahun 2013. (Badan Penelitian dan Pengembangan Kesehtan Kementerian Kesehatan RI Tahun 2013, 2013).

3. Unicef. Gizi Ibu \& Anak. Unicef Indones. 1-6 (2012).

4. TNP2K. 100 Kabupaten/ Kota Prioritas Untuk Intervensi Anak Kerdil (Stunting). (Tim Nasional Percepatan Penanggulangan Kemiskinan, 2017).

5. Kemenkes RI. Infodatin Pusat Data dan Informasi Kementerian Kesehatan RI Situasi Balita Pendek. (Kementerian Kesehatan RI Pusat Data dan Informasi, 2016).

6. Chirande, L. et al. Determinants of Stunting and Severe Stunting Among Under-fives in Tanzania : Evidence from Determinants of stunting and severe stunting among under-fives in Tanzania : evidence from the 2010 cross-sectional household survey. BMC Pediatr. 15, 1-13 (2015).

7. Kusharisupeni. Peran Status Kelahiran Terhadap Stunting Pada Bayi: sebuah studi prospektif. J Kedokt. Trisakti 23, 73-80 (2011).

8. Anisa, P. Faktor-faktor yang Berhubungan dengan Kejadian Stunting Pada Balita Usia 25-60 Bulan di Kelurahan Kalibaru Depok Tahun 2012. Fakultas Kesehatan Masyarakat Universitas Indonesia (Universitas Indonesia, 2012).

9. Hermina, H. \& Prihartini, S. Gambaran Keragaman Makanan Dan Sumbangannya Terhadap Konsumsi Energi Protein Pada Anak Balita Pendek (Stunting) Di. Bul. Penelit. Kesehat. 39, 62-73 (2011).

10. Adriani, M. \& Wirjatmadi, B. Pengantar Gizi Masyarakat. (Kencana, 2012).

11. Salguerio, M. J. et al. The Role of Zinc in the Growth and Development of Children. Nutrition 18, 510-519 (2002).

12. Hidayati, S. N. in Buku Ajar Nutrisi Pediatrik dan Penyakit Metabolik Jilid I Revisi 227-234 (Badan Penerbit IDAI, 2014).

13. Kristianti, H. Penyakit Akibat Kelebihan dan Kekurangan Vitamin, Mineral dan Elektrolit. (Citra Pustaka, 2010).

14. Fikawati, S., Syafiq, A. \& Veratamala, A. Gizi Anak dan Remaja. (PT RajaGrafindo Persada, 2017).

15. Kusudaryati, D. P. D. Kekurangan Asupan Besi dan Seng Sebagai Faktor Penyebab Stunting Pada 
Anak. Profesi 10, 57-61 (2014).

16. Ramli et al. Prevalence and Risk Factors for Stunting and Severe Stunting Among Under-fives in North Maluku Province of Indonesia. BMC Pediatr. 9, 1-10 (2009).

17. Rosha, B. C., Hardiansyah, T. \& Baliwati, Y. F. Analisis Determinan Stunting Anak 0-23 Bulan Pada Daerah Miskin di Jawa Tengah dan Jawa Timur. Panel Gizi Makan 35, 34-41 (2012).

18. Persagi, D. P. D. \& Tengah, J. Prosiding Seminar dan Simposium Nasional Nutrition and Dietetics To Combat Non Communicable Disease. (DPD PERSAGI Jawa Tengah, 2017).

19. Viridula, E. Y., Murti, B. \& Suryani, N. Path Analysis on the Effect of Biopsychosocial and Economic Factors during Gestational Period on the Risk of Stunting and Development in Children under Five, in Nganjuk, East Java. J. Heal. Promot. Behav. 1, 180-189 (2016).

20. MCA Indonesia. Stunting dan Masa Depan Indonesia. Millenn. Chall. Acc. - Indones. 2010, 25 (2013).

21. Kurniasari, Y., Juffrie, M. \& Jamil, M. D. Kadar kalsium serum pada anak stunting dan tidak stunting usia 24-59 bulan. J. Gizi Klin. Indones. 12, 108-115 (2016).

22. Rahmawati, A. \& Wirawanni, Y. Perbedaan Kadar Seng (Zn) Rambut Berdasarkan Derajat Stunting Pada Anak Usia 6-9 Tahun. J. Nutr. Coll. 1, 365372 (2012).

23. Ribeiro, A. S., Curtius, A. J. \& Pozebon, D. Determination of $\mathrm{As}, \mathrm{Cd}, \mathrm{Ni}$ and $\mathrm{Pb}$ in human hair by electrothermal atomic absorption spectrometry after sample treatment with tetramethylammonium hydroxide. Microchem. J. 64, 105-110 (2000).

24. Susilo, M. T. \& Widyastuti, N. Hubungan Kadar Seng ( Zn ) Rambut dengan Z-score Panjang Badan Menurut Umur ( PB / U ) Balita Usia 12-24 Bulan. J. Nutr. Coll. 2, 638-644 (2013).

25. Lowe, N. M., Fekete, K. \& Decsi, T. Methods of assessment of zinc status in humans. Am. J. Clin. Nutr. 89, 2040-2051 (2009).

26. Lemeshow, S. Besar Sampel Dalam Penelitian Kesehatan. (Gadjah Mada University Press, 1997).

27. Jatim, G. Peraturan Gubernur Jawa Timur Nomor 75 Tahun 2017 tentang Upah Minimum Kabupaten/Kota di Jawa Timur Tahun 2018. (2017).

28. Gibson, R. Principles Of Nutritional Assesment. (Oxford University, 2005).

29. Rani, N., Diffah, H. \& Sapja, A. The Correlation Between Zinc Source Dietary Intake dan Hair $\hat{a} €^{\mathrm{TM}}$ s Zinc Level on Stunting Incidence at Primary School Students of Malang Regency. IEESE Int. J. Sciience Technol. 6, 1-5 (2017).

30. Budiastutik, I., Wirjatmadi, B. \& Adriani, M. Pengaruh Suplementasi Zinc Sulfat dan Biskuit Terhadap Konsentrasi Zinc Rambut Balita (Program MP ASI Biskuit di Kertosono Jawa Timur).
Bul. Penelit. Sist. Kesehat. 14, 270-281 (2011).

31. Desyanti, C. \& Nindya, T. S. Hubungan Riwayat Penyakit Diare dan Praktik Higiene dengan Kejadian Stunting pada Balita Usia 24-59 Bulan di Wilayah Kerja Puskesmas Simolawang , Surabaya. Amerta Nutr. 1, 243-251 (2017).

32. Anugraheni, H. S. \& Kartasurya, M. I. Faktor Risiko Kejadoan Stunting pada Anak Usia 12-36 Bulan di Kecamatan Pati, Kabupaten Pati. J. Nutr. Coll. 1, 30-37 (2012).

33. Oktiva, B. R. \& Adriani, M. Perbedaan Kadar Zinc Rambut pada Anak Stunting dan Non Stunting Usia 12- 24 Bulan di Kelurahan Tambak Wedi Kenjeran , Surabaya The Difference of Hair Zinc Level on Stunted and Non Stunted Child Age 1224 Months in Tambak Wedi Kenjeran, Surabaya. Amerta Nutr 133-142 (2017). doi:10.20473/amnt.v1.i2.2017.133-142

34. Shokibi, A. \& Nuryanto. Hubungan Asupan Energi, Protein, Seng dan Kebugaran Fisik dengan Prestasi Belajar Anak Stunting di SDN Penganten I,II, dan III Kecamatan Klambu Kabupaten Grobogan. J. Nutr. Coll. 4, 71-78 (2015)

35. Paschalia, Y. P. M. Perbedaan Kadar Zinc dan Kejadian ISPA Serta Kejadian Diare pada Balita Stunting - Wasting dan Balita Normal di Puskesmas Nangapanda Kabupaten Ende. Info Kesehat. 12, 535-547 (2014).

36. Kemenkes RI. Peraturan Menteri Kesehatan Republik Indonesia Nomor 75 Tahun 2013 Tentang Angka Kecukupan Gizi Yang Dianjurkan Bagi Bangsa Indonesia. Jakarta 5-10 (2013).

37. Almatsier, S., Soetardjo, S. \& Soekatri, M. Gizi Seimbang Dalam Daur Kehidupan. (Gramedia Pustaka Utama, 2011).

38. Dewi, I. A. K. C. \& Adhi, K. T. Pengaruh Konsumsi Protein Dan Seng Serta Riwayat Penyakit Infeksi Terhadap Kejadian Stunting Pada Anak Balita Umur 24-59 Bulan Di Wilayah Kerja Puskesmas Nusa Penida III. Arc Com Heal. 3, 36-46 (2016).

39. Stephenson, K. et al. Consuming Cassava as a Staple Food Places Children 2-5 Years Old at Risk For Inadequate Protein Intake, an Observational Study in Kenya and Nigeria. Nutr. J. 9, 1-6 (2010).

40. Adriani, M. \& Wirjatmadi, B. Peranan Gizi dalam Siklus Kehidupan. (Kencana Prenada Media Group, 2012).

41. Sutomo, B. \& Anggraini, D. Y. Menu Sehat Alami untuk Batita dan Balita. (Demedia, 2010).

42. Brown, K. H., Peerson, J. M., Rivera, J. \& Allen, L. $H$. Effect of supplemental zinc on the growth and serum zinc concentrations of prepubertal children: a meta-analysis of randomized controlled trials $1-3$. Am. J. Clin. Nutr. 75, 10621071 (2002).

43. Dewi, K. D. P. Perbedaan Konsumsi Zinc Pada Anak Pendidikan Anak Usia Dini ( PAUD ) Yang Stunted Dengan Yang Tidak Stunted Di Kota Denpasar. J. Virgin 1, 70-78 (2015).

44. Pramono, A., Panunggal, B., Anggraeni, N. \& Rahfiludin, M. Z. Asupan Seng, Kadar Serum 
Seng, Dan Stunting Pada Anak Sekolah Di Pesisir Semarang. J. Gizi Pangan 11, 19-26 (2016).

45. Bening, S., Margawati, A. \& Rosidi, A. Zinc Deficiency As Risk Factor For Stunting Among Children Aged 2-5 Years. Universa Medica 36, 11-18 (2017).

46. Gibson, R. S. Zinc: The Missing Link in Combating Micronutrient Malnutrition in Developing Countries. in Zinc: The Missing Link in Combating Micronutrient Malnutrition in Developing Countries 65, 51-60 (Rank Prize Lecture, 2006).

47. Mardewi, K. W., Sidiartha, I. G. L. \& Gunawijaya, E. Low Serum Zinc and Short Stature in Children.
Pediatr. Indones. 56, 171-175 (2016).

48. Losong, N. H. F. \& Adriani, M. Perbedaan Kadar Hemoglobin , Asupan Zat Besi, dan Zinc pada Balita Stunting dan Non Stunting The Differences of Hemoglobin Level, Iron, and Zinc Intake in Stunting and non Stunting Toodler. Amerta Nutr 117-123 (2017). doi:10.20473/amnt.v1.i2.2017.117-123

49. Yuniastuti, A. Nutrisi Mikromineral \& Kesehatan. (UNNES PRESS, 2014).

50. Almatsier, S. Prinsip Dasar Ilmu Gizi. (PT. Gramedia Pustaka Utama, 2005). 